\title{
Physicochemical and Bacteriological Quality of groundwater in Kabul basin, Afghanistan
}

\author{
Ahmad Omid Afzali ${ }^{1}$ \\ ${ }^{I}$ Department of Geosciences, Academy of Sciences of Afghanistan.
}

\begin{abstract}
Groundwater in Kabul basin, Afghanistan was assessed for its physical, chemical and bacterial components. Kabul basin is divided in to five hydro-geologic sub-basins, water from 50 wells whose depths varies from 9 meters -71 meters was analyzed. The $\mathrm{pH}$, conductivity, total dissolved solids, temperature, chemical elements (cations and anion) and bacteriological content of the groundwater conform to the World Health Organization (WHO) and national standards for potable water. Some samples of groundwater examined contain bacteria especially, Escherichia coli and Coliforms which makes the water unsafe if consumed untreated.
\end{abstract}

Keywords: Hydrogeology, Potability, Aquifer, Coliform, Escherichia coli, W.H.O.

\section{Introduction}

Water is the most important and most essential for human life. According to the importance of water in the world the 21century has been called the century of water. Good quality water is an essential resource for the continuity of ecosystems. The development of water resources is a significant part of integrated community development policy. Lack of access to safe drinking water killed more than six million children every year.

Afghanistan is a landlocked country and doesn't have any sea, but this country is the source of about 75 billion cubic meters of water a year. Groundwater in some areas of Afghanistan due to lack of other water resources is one of the important sources to use it for drinking, agriculture and industries.

The Kabul area is an important center that provides an economic base for Afghanistan through, political and social - economic factors. More than seven million populations live in this area that is almost 20 percent of the country's population. By 2001 the population of Kabul was less than one million people while the estimated population in 2010 was around 5000000, by 2030 it is estimated that the Kabul population rises to 7000000 people, therefore about $20 \%$ of all Afghanistan population live in Kabul city and adjacent area of this city, Groundwater is the only source of water supply for civilians in Kabul. They use groundwater as their primary source of drinking water. Kabul Basin, especially Kabul city, has three main rivers that provide surface water for this basin, but due the time distribution (only three months flow during the year) and contamination of, these waters is not useable; therefore the role of groundwater is very important for this basin, figure.1.

Population growth, urbanization, unstandardized development, lack of legality effects on quality and quantity of groundwater resources in Kabul basin. The present project focuses on the evaluation of the groundwater quality and quantity in the Kabul basin by chemical, physical and bacteriological analyses to ensure its suitability for drinking and irrigation and in any other uses. The primary aim of this study is to evaluate the overall status of groundwater in the area of Kabul to know where we are and where we are going (Zektser, 2004) ${ }^{[1]}$.
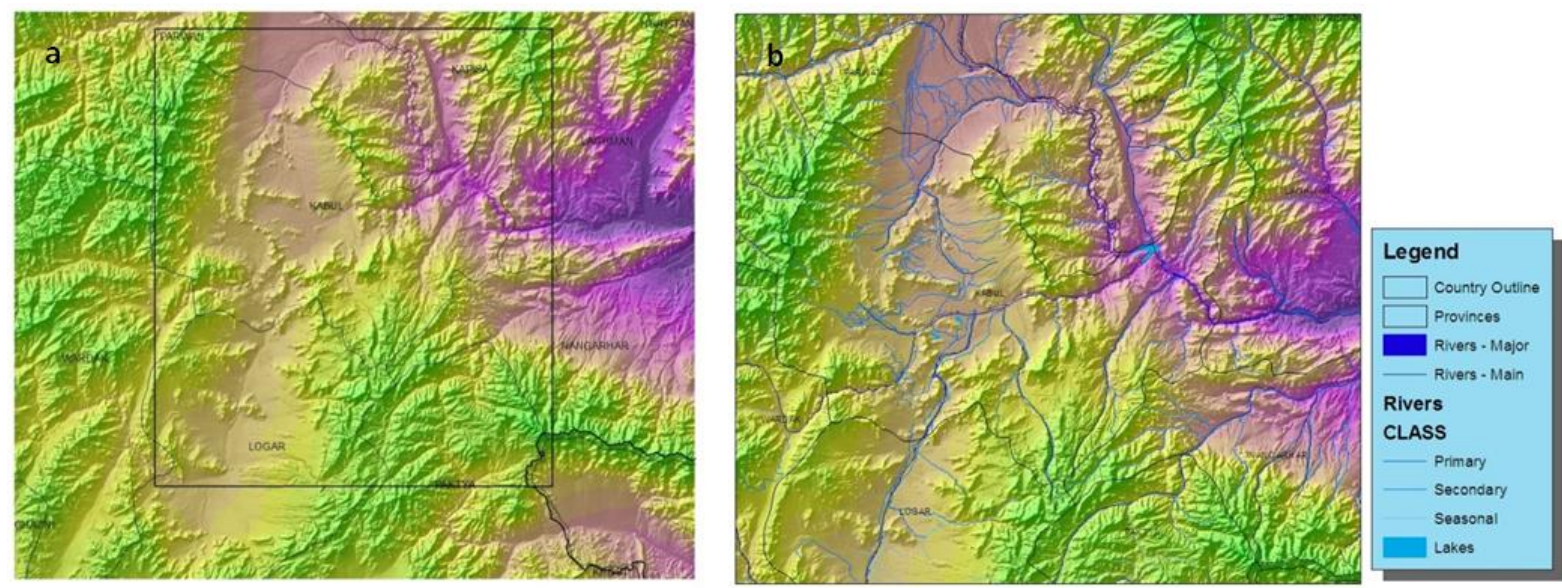

Figure.1: a. Geographic location of study area, b. Hydrography of Kabul basin. 


\subsection{Sample collection}

\section{Material and Method}

Water samples were collected from 50 boreholes from Kabul basin, stored in sterilized polythene bottles and covered after taking appropriate precautions to prevent contamination. The odor was recorded for each sample using human senses, physical, chemical and bacteriological analysis determined in lab.

\subsection{Physicochemical analysis}

\section{Results and discussion}

The results of the physicochemical analysis of groundwater in Kabul basin revealed that three physical parameters (temperature, color and taste) is unobjectionable and it permissible for drinking, but in Central Kabul sub-basin the electrical conductance value is $(3600 \mu \mathrm{s} / \mathrm{cm})$ and total dissolved solutions (TDS) value in is $(1625 \mathrm{mg} / \mathrm{l})$, these values are not within the levels recommended by World Health Organization (WHO) and national standards for potable water(Guidelines for drinking-water quality, WHO) ${ }^{[7]}$. Chloride values were below the (WHO) standard. Nitrate,Phosphate,Sulphateand Nitrite levels in the central Kabul sub-basin were high compared to the national and (WHO) standards. The levels of calcium and magnesium were very high compared to national and (WHO) standards. Groundwater at Kabul basin has maximum of (9mg/l) Potassium, while the (WHO) standards for Potassium concentration in groundwater is equal to $(10 \mathrm{mg} / \mathrm{l})$, therefore the potassium content in Kabul basin groundwater is below the (WHO) standard values. Sodium values ranged from $(6 \mathrm{mg} / \mathrm{l})$ to $(230 \mathrm{mg} / \mathrm{l})$ in Kabul basin groundwater samples, in some area indicating low values against the WHO guideline value $(200 \mathrm{mg} / \mathrm{l})$ for drinking water (Kinzelbach, 2015) ${ }^{[8]}$. In some area at levels above 200 $\mathrm{mg} / \mathrm{l}$, Sodium affects the taste of drinking water.Chromium and Arsenic was detectable insome samples. Aluminum, Fluoride, Iron, Copper and Boron values are different in Kabul basin groundwater samples, but the ranges of these elements is high than the (WHO) and national standards in Central Kabul sub-basin, table.1.

Table (1): Physicochemical parameters of Kabul basin groundwater.

\begin{tabular}{|c|c|c|c|c|c|}
\hline Parameters & Minimum Value & Average Value & $\begin{array}{l}\text { Maximum } \\
\text { Value }\end{array}$ & $\begin{array}{l}\text { National } \\
\text { Standards }\end{array}$ & $\begin{array}{l}\text { International } \\
\text { Standards }\end{array}$ \\
\hline $\mathbf{P h}$ & 7.59 & 7 & 8.12 & $6.5-8.5$ & 6.5 to 8.5 \\
\hline Total Alkalinity & 140 & 337 & 567 & - & - \\
\hline Bicarbonate & 145 & 283 & 430 & - & - \\
\hline Carbonate & 10 & 46.7 & 140 & - & - \\
\hline Chloride & 3.64 & 93.3 & 240 & 250 & 250 \\
\hline Sulphate & 5 & 103.9 & 326 & 250 & 250 \\
\hline Sulphite & 1 & 3.2 & 6 & - & - \\
\hline Sulphide & 0.01 & 0.01 & 0.02 & - & - \\
\hline Fluoride & 0.14 & 0.59 & 1.25 & 1.7 & 1.5 \\
\hline Nitrate & 3.1 & 21.85 & 54 & 50 & 50 \\
\hline Phosphate & 0.05 & 0.32 & 1.05 & 0.1 & 0.1 \\
\hline Boron & 0.025 & 0.35 & 2.4 & 0.5 & 0.5 \\
\hline Bromine & 0.05 & 0.52 & 2.97 & - & - \\
\hline Sodium & 6 & 90.3 & 230 & 200 & 200 \\
\hline Potassium & 0.3 & 3.78 & 9.3 & 10 & - \\
\hline Calcium & 23.6 & 67.61 & 531 & 250 & 200 \\
\hline Chromium & 0.01 & 0.01 & 0.03 & 0.05 & 0.05 \\
\hline Magnesium & 9 & 46.43 & 142 & 50 & 50 \\
\hline Ammonia & 0.01 & 0.07 & 0.21 & 1.5 & 1.5 \\
\hline Manganese & 0.001 & 0.0017 & 0.005 & 0.5 & 0.5 \\
\hline Copper & 0.001 & 0.18 & 1.4 & 0.5 & 2 \\
\hline Aluminum & 0.001 & 0.012 & 0.04 & 5 & 5 \\
\hline Iron & 0.04 & 0.14 & 1.7 & 0.3 & 0.3 \\
\hline Arsenic & 0.002 & 1.3 & 3 & 0.1 & 0.1 \\
\hline
\end{tabular}


Physicochemical and Bacteriological Quality of groundwater in Kabul basin, Afghanistan

\begin{tabular}{|l|l|l|l|l|l|}
\hline Silica & 0.74 & 14.49 & 30 & & \\
\hline Sub-basins & DehSabz & Shamali & Logar & Paghman & Central Kabul \\
\hline Color & & & & & \\
\hline Taste & Fair & Fair & Fair & Fair & Fair \\
\hline Temperature & Fair & Fair & Fair & Fair & Fair \\
\hline $\begin{array}{l}\text { Average Electrical } \\
\text { Conductivity }\end{array}$ & 17.13 & 20.61 & 14.77 & 15.49 & 19.16 \\
\hline $\begin{array}{l}\text { Average Turbidity } \\
\text { (NTU) }\end{array}$ & 4.05 & 616.6 & 1443.7 & 693.2 & 1226.15 \\
\hline Average TDS & 681.1 & 2.71 & 2.04 & 3.37 & 3.9 \\
\hline
\end{tabular}

\subsection{Bacteriological analysis}

The results of the bacteriological analysis of groundwater in Kabul basin revealed that in some area it is not safe for human consumption. Coliforms, Escherichia coli and fecal coliforms in the groundwater at Kabul basin especially in Central Kabul sub-basin are not within the levels recommended by World Health Organization (WHO) for drinkable water. However, the groundwater contains Coliforms and Escherchia coli which are not save to be consumed,table.2.

Table (2): Bacteriological contents in Kabul basin groundwater.

\begin{tabular}{|c|c|c|c|c|}
\hline \multicolumn{2}{|l|}{ Subbasins } & Total coli & E. coli & Fecal Coliforms \\
\hline \multicolumn{2}{|l|}{ Dehsabz } & 83.2 & 3.2 & 0 \\
\hline \multicolumn{2}{|l|}{ Shamali } & 36.91 & 1.9 & 0 \\
\hline \multicolumn{2}{|l|}{ Logar } & 128.05 & 16.9 & 0 \\
\hline \multicolumn{2}{|l|}{ Paghman } & 37.59 & 4.9 & 0 \\
\hline \multicolumn{2}{|c|}{ Central Kabul } & 615.19 & 52.8 & 32.6 \\
\hline \multirow{2}{*}{ Standards } & National & 0 & 0 & 0 \\
\hline & International (WHO) & 0 & 0 & 0 \\
\hline
\end{tabular}

\section{Discussion}

As Kabul population continues to grow up, there is increasing pressure to further exploit groundwater for various purposes which are basically not possible because of low thicknesses and low productivity of the aquifers. This trend will cause further negative consequences on the groundwater quality that will challenge our socio-economic development andenvironmental security. This vulnerability of the aquifer may not be reversible and the city of Kabul will face a severe shortage of drinking water and most probably increased water contamination in future (Aturamu, 2012) ${ }^{[6]}$. The results of all investigations show that the quality of groundwater in Kabul basin will not be recoverable, if this trend continues. Approximately only $10 \%$ of the inhabitants of Kabul city have access (intermittently) to the central water supply system.

The abundance of Escherichia coliform bacterial in Kabul basin is the answers for the question why diseases such as typhoid fever, paratyphoid, diarrhea attack, illness Sore attacks and other Skin diseases are common in the study areas (M. Thangarajan, 2007) ${ }^{[9]}$. The World Health Organization requires that potable water should be free from dangerous micro-organism especially Escherichia coli(Chukwuma O. B. 2011) ${ }^{[2]}$. However this organism can easily be destroyed through chlorination and boiling. It is encouraging to report that the groundwater at Kabul basin is physically and chemically almost drinkable as discussed previously in this research. The pollution of Kabul city groundwater caused by the presence of microorganism can be remedied by filtering, chlorination and boiling (G. Ehiowemwenguan, 2010) ${ }^{[3]}$. High nitrate in drinking water leads to methemoglobinemia cases in babies, and could indicate that there was little or no seepage of domestic sewage, or agricultural leaching or runoff water.High levels of Sulphate cause diarrhea and dehydration. When there is high content of calcium and magnesium in drinking water, it could result to kidney or bladder stones. This could be attributed to industries and nonstandard septic tanks, but fortunately the value of this toxic element is not high than the (WHO) standards (Aydin, A.2007) ${ }^{[5]}$ 


\section{Conclusions}

Among the five hydro-geologic sub-basins, $30 \%$ of the samples are not suitablefor drinking. TheCentral Kabul sub-basin (Kabul city) has the most contaminated water. About all of the analyzed samples (99.5\%) in Central Kabul sub- basin are contaminated by bacteria (total and fecal coliforms); these wells are not suitable for drinking. The analysis exhibits that bacterial contamination was the maximum in wells located at the center of the Kabul city; this may be due to using the residential septic tanks. It was also discovered that the quality of groundwater is suitable for irrigation in the target aquifer except in a few locations.

The contaminated water in Kabul basin groundwater can be made completely drinkable by scientific treatment that is: filtration, chlorination and boiling.

\section{References}

[1]. Zektser, Igor S, groundwater resources of the world and their uses, UNESCO, IHP-VI, series on groundwater, published on 2004, pages 345 .

[2]. Chukwuma O. B. Okoye and Gold C. Adiele, Physico-chemical studies and bacteriological assay of borehole waters in Ezinihitte, Nigeria, Department of Pure and Industrial Chemistry, University of Nigeria, 2011.pages19.

[3]. G. Ehiowemwenguan and others, Physico-Chemical and Bacteriological Quality of Borehole Water in Eyaen Community Area of Edo State, Nigeria,Department of Microbiology, University of Benin.

[4]. APHA, American Public Health Association, Guideline for potable water. 7th edition, (1992), New York: WHO Press pages 11.

[5]. Aydin, A. . The microbial and physico-chemical quality of groundwater in west Thrace, Turkey, Polish Journal of Environmental Studies (2007) pages 14

[6]. Aturamu, AdeyinkaOluyemi, Physical, Chemical and Bacterial Analyses of Groundwater in Ikere Township, Southwestern Nigeria, Department of Geology, University of Leicester, Leicester, LE1 7RH. United Kingdom, 2012, pages 8.

[7]. Guidelines for drinking-water quality [electronic resource]: incorporating first addendum, Vol.1, world health organization, Recommendations. - 3rd ed, Electronic version for the Web.

[8]. Kinzelbach Wolfgang and others, Sustainable groundwater management probl-ems and scientific tools, Institute for Hydromechanics and Water Resources Management, ETH Zürich, Switzerland, 2015, pages 6

[9]. M. Thangarajan, Groundwater Resource Evaluation, Augmentation, Contam-ination,Restoration, Modeling and Management, National Geophysical Research InstituteHyderabad, India, 2007 Capital Publishing Company, pages 400.

[10]. Sustainable Groundwater Management Program (Strategic Plan), California Department of Water Resources, March 9, 2015, pages 32. 